\title{
Fabrication of Porcelains Having Improved Thermal Shock Resistance by a Lithium Solution Infiltration Method
}

\author{
Sang-Moon $\mathrm{Na}^{*}$ and Sang-Jin Lee**广 \\ *YJC Co., LTD, Hampyung 525-813, Korea \\ **Department of Advanced Materials Science and Engineering, Mokpo National University, Muan 534-729, Korea \\ (Received January 7, 2013; Revised March 1, 2013; Accepted March 6, 2013)
}

\section{리튬용액침투법에 의한 내열충격성이 향상된 세라믹 제조}

\author{
나상문* - 이상진**† \\ *(주)와이제이씨 \\ **국립목포대학교 신소재공학전공
}

(2013년 1월 7일 접수 ; 2013년 3월 1일 수정 ; 2013년 3월 6일 채택)

\begin{abstract}
Porcelain with high thermal shock resistance was successfully fabricated by a lithium solution infiltration method with a lithium hydroxide solution. Lithium hydroxide solutions having various lithium concentrations were infiltrated into pre-sintered porcelain bodies. The porcelain sample infiltrated by the $9 \mathrm{wt} \%$ lithium solution and heat treated at $1250^{\circ} \mathrm{C}$ for $1 \mathrm{~h}$ showed a low thermal expansion coefficient of $1.0 \times 10^{-6} / \mathrm{C}$ with excellent thermal shock resistance. The highly thermally resistant porcelain had a welldeveloped $\beta$-spodumene phase with the general phases observed in porcelain. Furthermore, the porcelain showed a denser structure of $2.41 \mathrm{~g} / \mathrm{cm}^{3}$ sintering density and excellent whiteness in comparison with commercial thermally resistible porcelains. The lithium hydroxide in the samples readily reacted with moisture, and liquid phase reactants were formed during the fabrication process. In the case of an excess amount of lithium in the sample body, the lithium reactants were forced to the surface and re-crystallized at the surface, leaving large pores beneath the surface. These phenomena resulted in an irregular structure in the surface area and led to cracking in samples subjected to a thermal shock test.
\end{abstract}

Key words: Porcelain, Thermal resistance, $\beta$-spodumene, Microstructure, Lithium solution

\section{1. 서 론}

세라믹스는 금속 및 고분자 재료와 비교하여 고내열성, 고내식성, 고경도 등의 우수한 물성으로 인하여 응용 및 실용화에 대한 연구가 계속적으로 요구되고 있는 재료이 다. 특히 저 열팽창계수를 보이는 내열 충격성이 우수한 세라믹 재료는 가정용 및 산업용으로 다양한 용도로 응 용되고 있다. ${ }^{1)}$ 이 중에서도 주로 결정화 유리(glass ceramics) 형태로 이용되는 Lithium Aluminum Silicate(LAS)계 세라믹 스는 매우 낮거나 (-)에 가까운 열팽창계수를 지니며, 열 과 화학적으로 내구성이 훌륭하여 높은 열충격 저항성을 보이는 내열 세라믹스 재료로 널리 연구되어 사용되고 있 다. ${ }^{2-5)} \mathrm{LAS}$ 계 결정상으로는 eucryptite $\left(\mathrm{Li}_{2} \mathrm{O} \cdot \mathrm{Al}_{2} \mathrm{O}_{3} \cdot 2 \mathrm{SiO}_{2}\right)$ 와

\footnotetext{
${ }^{\dagger}$ Corresponding author : Sang-Jin Lee

E-mail : lee@mokpo.ac.kr,

Tel : +82-61-450-2493 Fax : +82-61-450-2498
}

spodumene $\left(\mathrm{Li}_{2} \mathrm{O} \cdot \mathrm{Al}_{2} \mathrm{O}_{3} \cdot 4 \mathrm{SiO}_{2}\right)$ 을 들 수 있으며, 이들은 매우 낮은 열팽창계수를 보이는 물질로서, (-) 열팽창계수를 보 이는 $\beta$-eucryptite는, 이보다 $\mathrm{SiO}_{2}$ 양이 많은 $\beta$-spodumene의 많은 고용체 결정상에 비하여 불안정한 상태를 보인다. ${ }^{6-8)}$ 이러한 LAS계 결정상을 이용하여 내열 세라믹스를 개발 하는 연구는 오래 전부터 연구되어 왔으며, 내열자기 분 야의 응용에 있어서는 합성에 의한 $\beta$-spodumene 결정상 을 유도하여 열팽창계수를 낮추는 방법을 쓰고 있다. ${ }^{9,10)}$ $\beta$-spodumene은 강도, 파괴인성, 및 열전도도 값이 다른 구 조재료에 비해 작지만, 낮은 열팽창계수로 인해 열충 격 저항성이 우수한 재료로 널리 사용되고 있으며, 이를 위하여 많은 새로운 $\beta$-spodumene 합성법이 개발되고 있 다. ${ }^{11-19)}$ 국내에서 내열자기로의 응용은 일반 삼성분 계 생활자기 소지를 기초로 리튬 성분이 함유된 petalite $\left(\mathrm{Li}_{2} \mathrm{O} \cdot \mathrm{Al}_{2} \mathrm{O}_{3} \cdot 8 \mathrm{SiO}_{2}\right)$ 광물을 분말화하여 첨가함으로써 최종 제품에 $\beta$-spodumene 상을 생성시켜 열충격 저항성을 높 이고 있다. ${ }^{20)}$ 그러나 petalite는 국내에 존재하지 않아 전 
량을 외국에서 수입하여야 하며, 일반 생활자기에 쓰이는 삼성분계 소지와 혼합 시에도 제품단가 측면에서 일정량 이상으로 혼합이 불가능하며, 이렇게 제조된 내열자기는 제품의 내열충격성을 유지하기 위하여 소결체의 치밀화 를 어느 정도 이상은 높일 수 없는 단점이 있다. 따라서 제품의 심미성이 떨어지고 유약 적용에 한계가 있게 된 다. 따라서 치밀화와 백색도를 유지하며 내열충격성을 지 니는 새로운 내열자기 소지의 개발은 내열자기 제조업체 를 비롯한 여러 세라믹 분야에서 연구 되어야 할 과제라 볼 수 있다.

본 연구에서는 이러한 LAS계 내열 세라믹스를 제조함 에 있어, 결정화 유리나 리튬이 함유된 고상원료를 사용 하여 합성하는 방법을 사용하지 않고, 간단하면서 새로운 제조방법인 리튬용액침투법(lithium solution infiltration method)을 이용하여 내열 세라믹스를 제조하였다. 일반 생활자기에 사용되는 삼성분계 조성에 리튬 성분을 용액 형태로 침투시켜 열처리 함으로써 $\beta$-spodumene의 합성과 소지의 치밀화를 동시에 행하고, 내열충격성과 높은 백색 도를 함께 만족하는 새로운 제조방법을 시도하였다. 연구 를 위하여 리튬용액의 농도와 소성온도에 따른 최종 결 정상의 변화를 고찰하였으며, 각 시편의 열적 특성을 미 세구조 관찰 및 물성변화를 통하여 고찰하였다. 이를 통 하여 리틈용액침투법을 이용한 내열 세라믹스 제조 응용 가능성을 알아보았다.

\section{2. 실험방법}

일반 생활자기용 삼성분계 소지는 고령토 $30 \mathrm{wt} \%$, 도석 $20 \mathrm{wt} \%$, 점토 $24 \mathrm{wt} \%$, 규석 $15 \mathrm{wt} \%$, 장석 $10 \mathrm{wt} \%$, 활석 $1 \mathrm{wt} \%$ 를 분말화하여 혼합 슬러리 상태로 제조하였다. 혼 합은 테프론 용기에 크기가 다른 알루미나 볼과 용매로 증류수를 사용하여 24시간 동안 습식 볼밀링 하였다. 제 조된 슬러리는 석고 몰드를 사용하여 슬립캐스팅 성형방 법으로 여러 형태의 성형체를 제조하였다. 건조를 거친 성형체들은 열린 기공을 최대한 유지하면서, 리튬용액 침 투공정 작업에 적합한 기공률과 성형강도 부여를 위하여 대기분위기에서 $900^{\circ} \mathrm{C}, 1$ 시간 동안 1 차 소성하였다.

리튬용액 제조를 위하여 수산화리튬 $(\mathrm{LiOH})$ 을 사용하였 고, 증류수의 혼합량을 변화시키며 용액의 농도를 조절하 였다. 용액 내의 수산화리틈 함량은 $0 \mathrm{wt} \%$ 에서 $16 \mathrm{wt} \%$ 까지 조절하였다. 농도가 조절된 각각의 수산화리틈 수용 액에 1 차 소성된 시편을 1 분간 담근 상태로 유지하여 용 액의 침투가 충분히 이루어지도록 하였다. 이후 $80^{\circ} \mathrm{C}$ 에서 24 시간 동안 건조된 시편은 대기분위기에서 분당 $4^{\circ} \mathrm{C}$ 의 승온속도로 $1150 \sim 1250^{\circ} \mathrm{C}$ 까지 소성 온도를 변화시켜가며 열처리하였다.

최종 열처리된 시편의 상분석을 위하여 $\mathrm{X}$ 선 회절분석
기(Rigaku, DMAX 2200, Tokyo, Japan)를 사용하여 $\mathrm{CuK}_{\alpha}$ 특성 $\mathrm{X}$-선 파장을 이용, $40 \mathrm{kV}, 30 \mathrm{~mA}$ 의 조건하에 서 분석을 실시하였다. 시편의 선형 수축률은 버어니어캘 리퍼스를 이용하여 5 번 이상 측정한 값을 평균하여 데이 터화 하였고, 밀도측정과 기공률 및 흡수율은 일정한 모 양의 디스크 타입 시편을 이용하여 아르키메데스 방법에 의해 측정하였다. 측정 시 시편의 수분 반응성을 고려하 여 케로진(kerosene)을 사용하였다. 시편의 내열충격성을 알아보기 위하여 각 시편을 급열이 가능한 노에 넣은 후 $600^{\circ} \mathrm{C}$ 까지 30 분 동안 승온 시킨 후 바로 상온의 물에 넣 어 급냉 시켰다. 이 같은 급열, 급랭공정을 3회 반복하여 열충격 테스트를 실시하였다. 소결된 샘플과 열충격 테스 트 이후의 샘플의 미세구조와 균열여부를 관찰하기 위하 여 시편을 $\mathrm{Au}-\mathrm{Pd}$ 로 코팅하여 주사전자현미경(SEM, Model S3500, Hitachi, Tokyo, Japan)을 사용하여 관찰하였다. 혼 합된 출발분말의 조성은 동종의 전자현미경에 부착된 $\mathrm{EDAX}$ 분석을 통하여 조사하였다. 시편의 열팽창계수는 소결된 샘플을 $500 \times 10 \mathrm{~mm}$ 의 크기의 원기둥 모양으로 가 공하여 Dilatometer(DIL 402 PC, Netzsch, Germany)를 이용하여 승온속도 $10^{\circ} \mathrm{C} / \mathrm{min}$ 으로 상온에서 $1000^{\circ} \mathrm{C}$ 까지 측 정하였다.

\section{3. 결과 및 고찰}

$\mathrm{EDAX}$ 를 사용하여 분석한 3성분계 소지용 출발분말의 조성을 Table 1에 나타내었다. 일반 삼성분계 소지에서 관 찰되는 $\mathrm{Al}_{2} \mathrm{O}_{3}, \mathrm{SiO}_{2}$ 를 주성분으로 하는 $\mathrm{K}_{2} \mathrm{O}, \mathrm{Na}_{2} \mathrm{O}$ 및 $\mathrm{MgO}$ 가 관찰되었다.

수산화리튬의 농도를 달리하여 제조한 수용액을 1차 소 성체에 침투시켜 온도 별로 열처리한 결과, 일반적으로 리틈의 농도가 증가할수록 그리고 소성온도가 높을수록 소지 내 $\beta$-spodumene 합성량이 증가하였다. 본 논문에서 는 수산화리튬의 농도를 달리하여 실험한 결과 중에서 대 표적인 물성 차이를 보인 $1 \mathrm{wt} \%, 9 \mathrm{wt} \%, 16 \mathrm{wt} \%$ 농도에 서 실험한 데이터를 중심으로, 리틈을 첨가하지 않고 열처

Table 1. Composition of Powder Mixture as Starting Material

\begin{tabular}{ccc}
\hline Element & Weight $\%$ & Atomic\% \\
\hline C K & 1.50 & 2.39 \\
O K & 58.29 & 69.89 \\
Na K & 0.89 & 0.74 \\
Mg K & 0.08 & 0.06 \\
Al K & 10.96 & 7.79 \\
Si K & 27.23 & 18.60 \\
K K & 1.06 & 0.52 \\
Total & 100.00 & \\
\hline
\end{tabular}




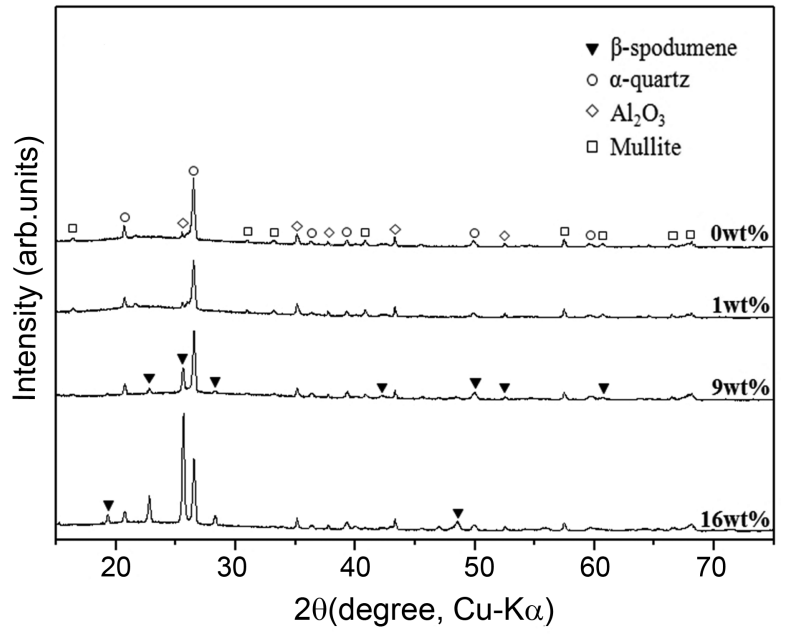

(a)

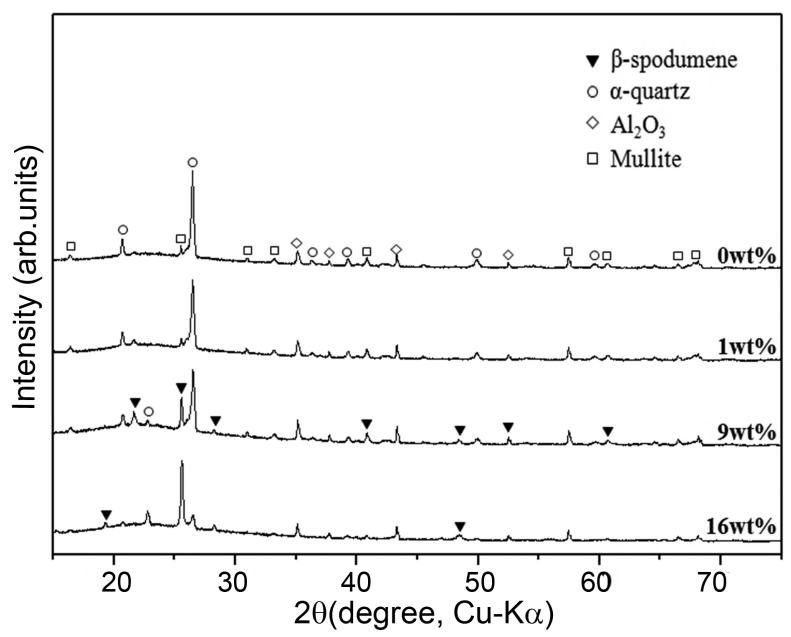

(b)

Fig. 1. XRD patterns of samples heat-treated at (a) $1150^{\circ} \mathrm{C}$ and (b) $1250^{\circ} \mathrm{C}$ for $1 \mathrm{~h}$ prepared from various lithium concentrations.

리만 시행한 시편과 비교해가며 결과를 서술하였다. Fig. 1 에 열처리 온도와 수산화리틈의 농도를 달리한 각 샘플 의 XRD 분석에 의한 결정화 거동을 나타내었다. XRD 분석을 위하여 벌크 상태의 각 시편을 분쇄한 후 분말화 하여 측정하였다. 리틈 침투가 일어나지 않은 $0 \mathrm{wt} \%$ 에서 는 두 온도 모두에서 일반 생활자기에서 관찰되는 mullite, $\alpha$-quarts, $\mathrm{Al}_{2} \mathrm{O}_{3}$ 결정상이 관찰되었다. $1 \mathrm{wt} \%$ 에서는 $1250^{\circ} \mathrm{C}$ 에서 매우 미소한 $\beta$-spodumene 피크가 관찰되기 시작하 였으며, 농도가 증가할수록 $\beta$-spodumene 피크는 증가하여 $9 \mathrm{wt} \%$ 에서는 주 결정상으로 관찰되었고, $16 \mathrm{wt} \%$ 에서는 $\alpha-$ quarts 피크보다 상대적으로 큰 $\beta$-spodumene 피크를 보였 다. 이 같은 현상은 $1150^{\circ} \mathrm{C}$ 보다 약간의 비정질 상이 동 반되는 $1250^{\circ} \mathrm{C}$ 에서 더욱 뚜렷이 관찰되었으며, 데이터 상 에 나타내지 않은 $1150^{\circ} \mathrm{C}$ 와 $1250^{\circ} \mathrm{C}$ 사이에서의 $\mathrm{XRD}$ 분 석결과도 온도가 올라갈수록 이 같은 경향을 나타내었다.
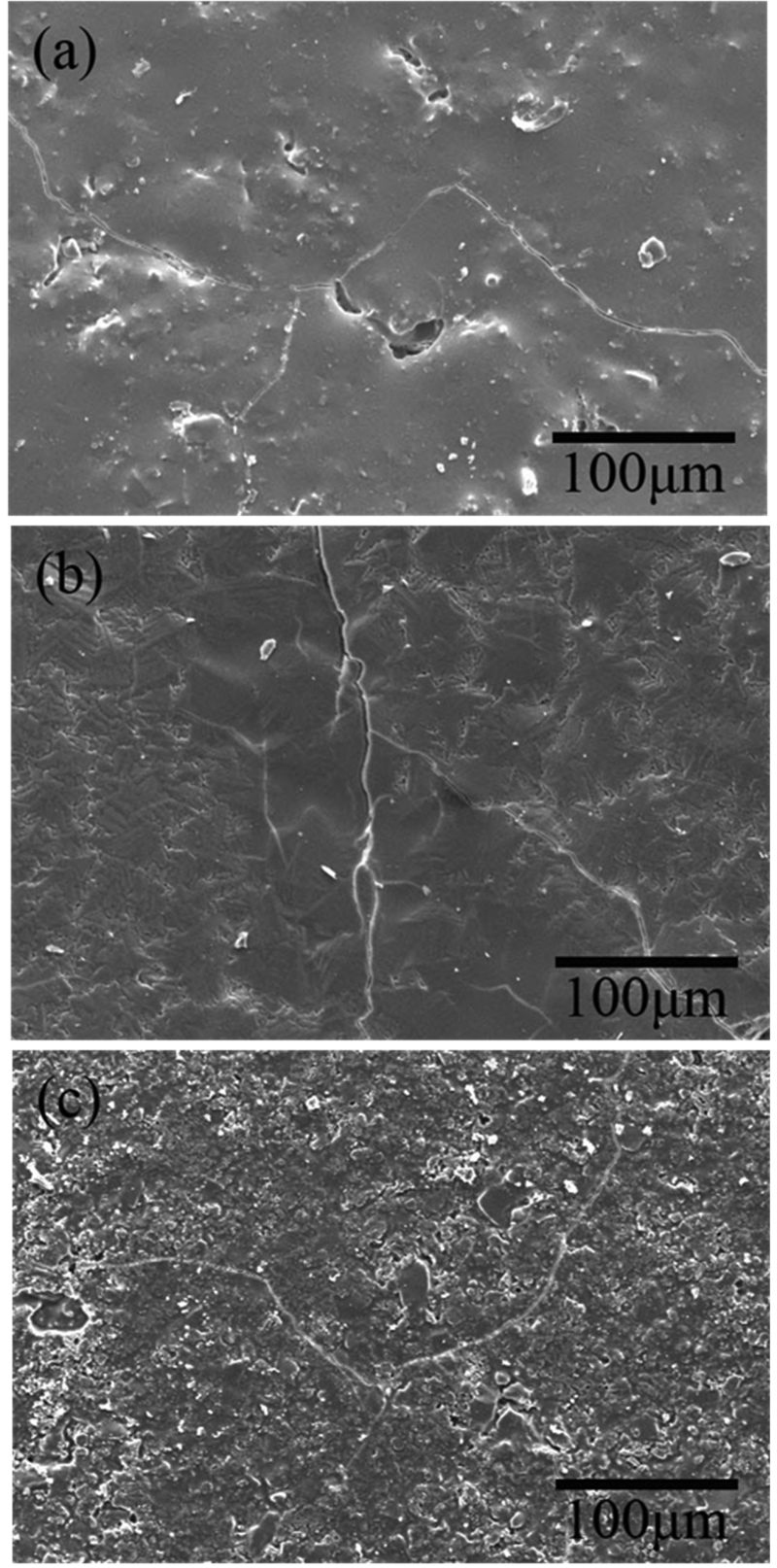

Fig. 2. Surface microstructures of thermal shock tested samples heat-treated at $1150^{\circ} \mathrm{C}$ for $1 \mathrm{~h}$, infiltrated with (a) $1 \mathrm{wt} \%$, (b) $9 \mathrm{wt} \%$, and (c) $16 \mathrm{wt} \%$ lithium solution.

또한 $\mathrm{Al}_{2} \mathrm{O}_{3}$ 와 mullite 피크도 온도가 상승함에 따라 상대 적으로 증가하는 경향을 보였다.

각 농도와 소성온도에서 제조된 샘플의 열충격 테스트 실험 후 샘플의 표면상태를 Fig. 2와 3에 각각 나타내었 다. 리튬용액을 침투시키지 않은 시편들은 모든 경우에 있어 첫 번째 열충격 테스트 시 심한 균열과 함께 파괴 가 일어났다. $1150^{\circ} \mathrm{C}$ 에서 열처리 한 경우(Fig. 2), 리튬용 액 농도에 따라 약간의 차이는 있으나, 표면에 모두 열충 격에 의한 균열이 발견되었고, 이것은 $1150^{\circ} \mathrm{C}$ 에서 $\beta$ 

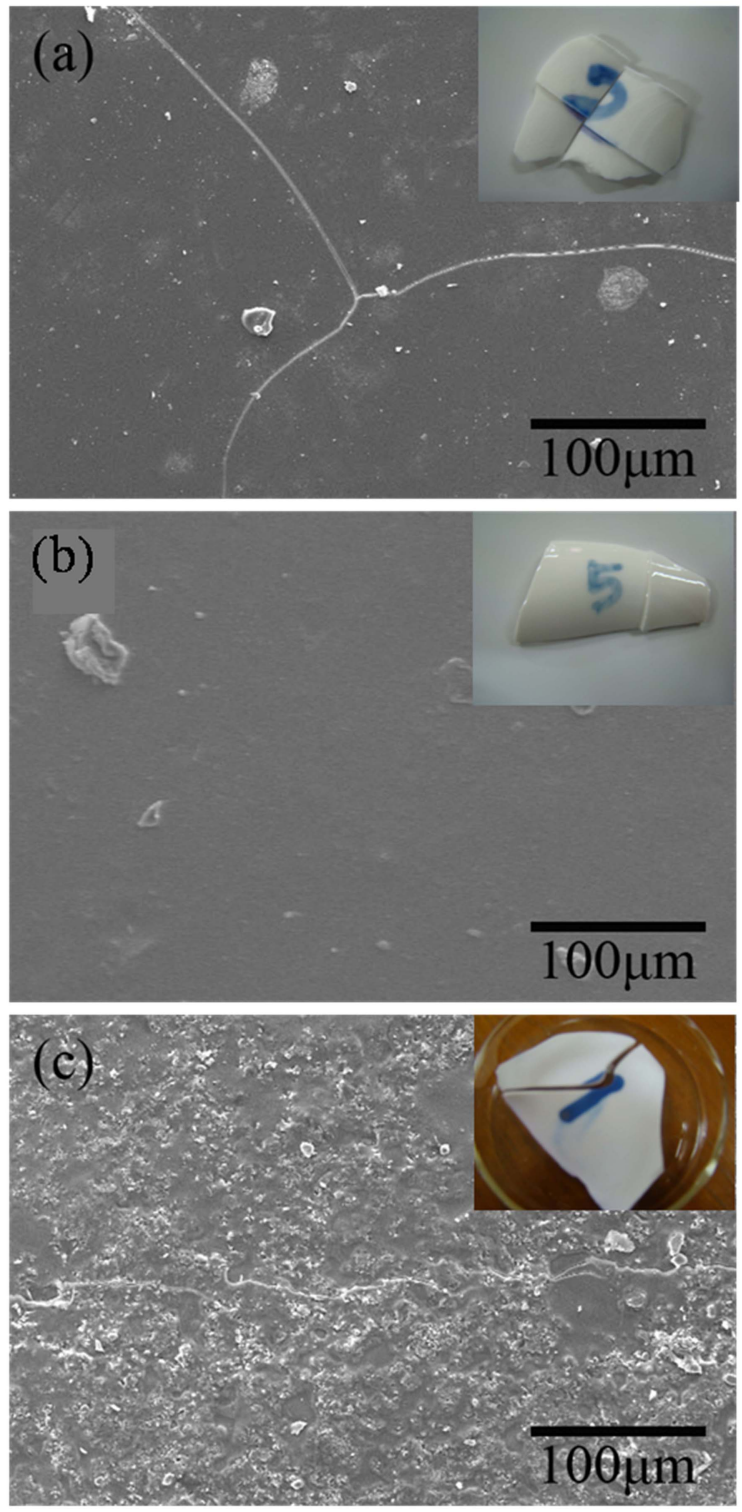

Fig. 3. Surface microstructures of thermal shock tested samples heat-treated at $1250^{\circ} \mathrm{C}$ for $1 \mathrm{~h}$, infiltrated with (a) $1 \mathrm{wt} \%$, (b) $9 \mathrm{wt} \%$, and (c) $16 \mathrm{wt} \%$ lithium solution.

spodumene의 충분한 결정화가 이루어지지 않아 나타 난 현상이라 생각된다. $1250^{\circ} \mathrm{C}$ 에서 소성한 시편의 경우 (Fig. 3), $9 \mathrm{wt} \%$ 농도에서 제조된 시편의 경우에만 균열이 발견되지 않았다. 열충격 테스트 후 균열이 발견된 시편
들은 외부충격에 의하여 쉽게 파괴가 일어났다. 특이할만 한 사항은 XRD 고찰 (Fig. 1(b))에서 보듯이 상대적으로 발달된 $\beta$-spodumene 결정상을 보이는 $16 \mathrm{wt} \%$ 리튬용액으 로부터 제조된 시편에서 열충격 테스트 후 균열이 관찰 되었고, 파괴가 일어났다는 점이다. 관찰된 유리상과 $\alpha$ 코런덤과 뮬라이트 결정상은 $9 \mathrm{wt} \%$ 농도에서 제조된 시 편에서도 동일하게 관찰되었다. 그러나 제조된 시편의 표 면을 관찰해 볼 때, $9 \mathrm{wt} \%$ 와 $16 \mathrm{wt} \%$ 에서 제조된 시편이 서로 상이한 표면상태를 나타내었는데, Fig. 3에서 보듯 이 $9 \mathrm{wt} \%$ 리튬용액으로 제조된 시편의 경우는 유리상과 같은 매우 매끈한 표면을 보이는 반면에, $16 \mathrm{wt} \%$ 리튬용 액으로 제조된 시편은 이에 비하여 거친 표면상태를 보 이고 있다. 이 같은 차이에서부터 서로 상이한 열충격 저 항성을 보인다고 판단하고, 각 시편의 소결 후 물성과 시 편의 표면 결정상을 관찰하였다.

Table 2에 수산화리튬의 농도를 달리한 수용액을 침투 하고 $1250^{\circ} \mathrm{C}$ 에서 열처리 한 시편의 리튬용액 농도에 따 른 물성을 나타내었다. 밀도는 리튬용액의 농도가 커질수 록 저밀도의 $\beta$-spodumene 합성에 의하여 감소하는 경향 을 보였으며, 수축률 역시 감소하였다. 기공률과 흡수율 은 리튬이 적용되지 않은 시편에 비하여 리튬용액을 흡 수시킨 경우 갑작스런 감소를 보이는데, 특히 흡수율의 감소는 $9 \mathrm{wt} \%$ 까지는 시편 표면을 덮은 유리상의 존재로 말미암아 표면의 구조가 매우 치밀해졌기 때문으로 판단 되며, $16 \mathrm{wt} \%$ 시편의 경우는 기공률과 흡수율이 다시금 증가하는 현상을 보였다. XRD 결과 (Fig. 1(b))에서 모두 유리상이 관찰되었지만, $9 \mathrm{wt} \%$ 와 $16 \mathrm{wt} \%$ 에서 제조한 시 편에서 이러한 물성변화와 열충격저항의 차이가 나타나 는 원인을 고찰하기 위하여 제조된 시편의 표면 결정상 을 고찰하였다. Fig. 4 에 $1250^{\circ} \mathrm{C}$ 에서 열처리 된 시편의 리 튬용액 농도에 따른 각 벌크시편의 표면 XRD 분석결과 를 나타내었다. $9 \mathrm{wt} \%$ 리튬용액으로부터 제조된 시편의 경우는 표면에서 유리상과 약간의 $\mathrm{Al}_{2} \mathrm{O}_{3}$ 상이 관찰되었 으나, $16 \mathrm{wt} \%$ 리튬용액으로 제조된 시편의 경우는 발달 된 $\beta$-spodumene과 eucryptite 결정상이 관찰되었다. 이러 한 상이한 관찰결과는 매우 흥미로운 결과라 볼 수 있으 며, 모두 샘플표면의 수산화리튬 성분이 제조과정 중에 외부로 용출되어 나타난 현상이라 판단된다. ${ }^{21,22)}$ 수분저 항성이 약하며 불안정한 상태로 존재하는 리튬 화합물은

Table 2. Density, Shrinkage, Porosity, and Absorption of Porcelains Heat-treated at $1250^{\circ} \mathrm{C}$, Prepared with Various Lithium Concentrations

\begin{tabular}{ccccc}
\hline & Density $\left(\mathrm{g} / \mathrm{cm}^{3}\right)$ & Shrinkage $(\%)$ & Porosity (\%) & Absorption $(\%)$ \\
\hline $0 \mathrm{wt} \%$ & 2.52 & 12.05 & 1.92 & 0.58 \\
$1 \mathrm{wt} \%$ & 2.50 & 9.15 & 0.38 & 0.14 \\
$9 \mathrm{wt} \%$ & 2.41 & 8.13 & 0.45 & 0.11 \\
$16 \mathrm{wt} \%$ & 2.28 & 8.02 & 1.51 & 0.77 \\
\hline
\end{tabular}




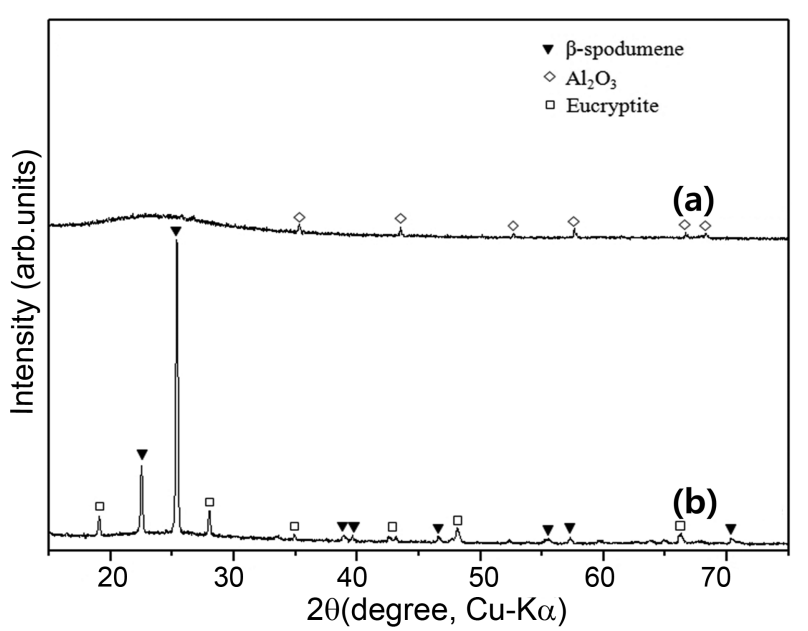

Fig. 4. XRD patterns of sample surfaces heat-treated at $1250^{\circ} \mathrm{C}$, infiltrated with (a) $9 \mathrm{wt} \%$ and (b) $16 \mathrm{wt} \%$ lithium solution.

제조공정 중 혹은 열처리 중 대기중의 수분과 쉽게 반응 하고, 반응에 의해 생성된 액상형태의 리튬 화합물은 쉽 게 표면으로 용출이 가능하다. 이러한 결과를 열충격 저 항성 테스트 결과와 연관시켜 볼 때, $9 \mathrm{wt} \%$ 의 경우 표면 의 유리상은 리튬성분이 함유된 저팽창 LAS계 유리조성 을 가지고 있는 것으로 판단되며, 시편 내부의 결정상과 열팽창 차이가 크지 않아 열충격저항 테스트에 잘 견디 는 것으로 판단된다. $16 \mathrm{wt} \%$ 의 경우는 시편 내부에 비하 여 표면에 상대적으로 많은 양의 리튬성분이 존재하리라 판단되고, 이로 말미암아 표면에 $\beta$-spodumene과 eucryptite 결정상이 관찰되어 열팽창성이 0 에 가까운 표면구조를 보 일 것으로 판단된다. 이러한 표면 결정상은 $\beta$-spodumene 이 주 결정상을 보인 내부 결정상과 별 차이가 없음에도 (Fig. 1(b)) 열충격 테스트 시 표면 균열과 파괴가 발생되 는 이유는 리튬성분의 과다용출로 인한 표면 미세구조의 심한 불균일성에서 그 원인이 있다고 생각된다.

이러한 결과를 좀 더 확인하기 위하여 시편의 표면과 내부를 동시에 관찰할 수 있는 표면부분을 연마한 파단 면의 미세구조를 Fig. 5 와 6에 각각 나타내었다 저배율의 Fig. 5 에서는 리튬농도에 따른 확연한 미세구조 차이를 보 여주고 있는데, $16 \mathrm{wt} \%$ 의 경우 내부에 큰 기공이 관찰되 며, 이것은 과량의 수산화리튬으로 말미암아 수분과의 반 응물이 다량 생성되고, 제조과정 중 리튬을 함유한 액상의 불규칙한 분포와 이들의 표면이동으로 말미암아 나타난 결 과라 생각되며, 이러한 큰 기공에 의하여 열충격 테스트 시 내부 균열이 발생하고, 이것은 열처리 후 약한 열충격 저 항성을 보이는 원인이 되었다고 생각된다. Fig. 5의 미세구 조 보다 고배율로 관찰된 Fig. 6의 결과에서 보듯이, $9 \mathrm{wt} \%$ 의 경우 (Fig. 6 (b)) 표면을 덮고 있는 $\mathrm{Li}$ 계 유리상 을 관찰할 수 있으며, $16 \mathrm{wt} \%$ 의 경우 (Fig. 6(c)) 결정화 된 표면을 관찰 할 수 있었다. 표면에 용출된 수산화리튬
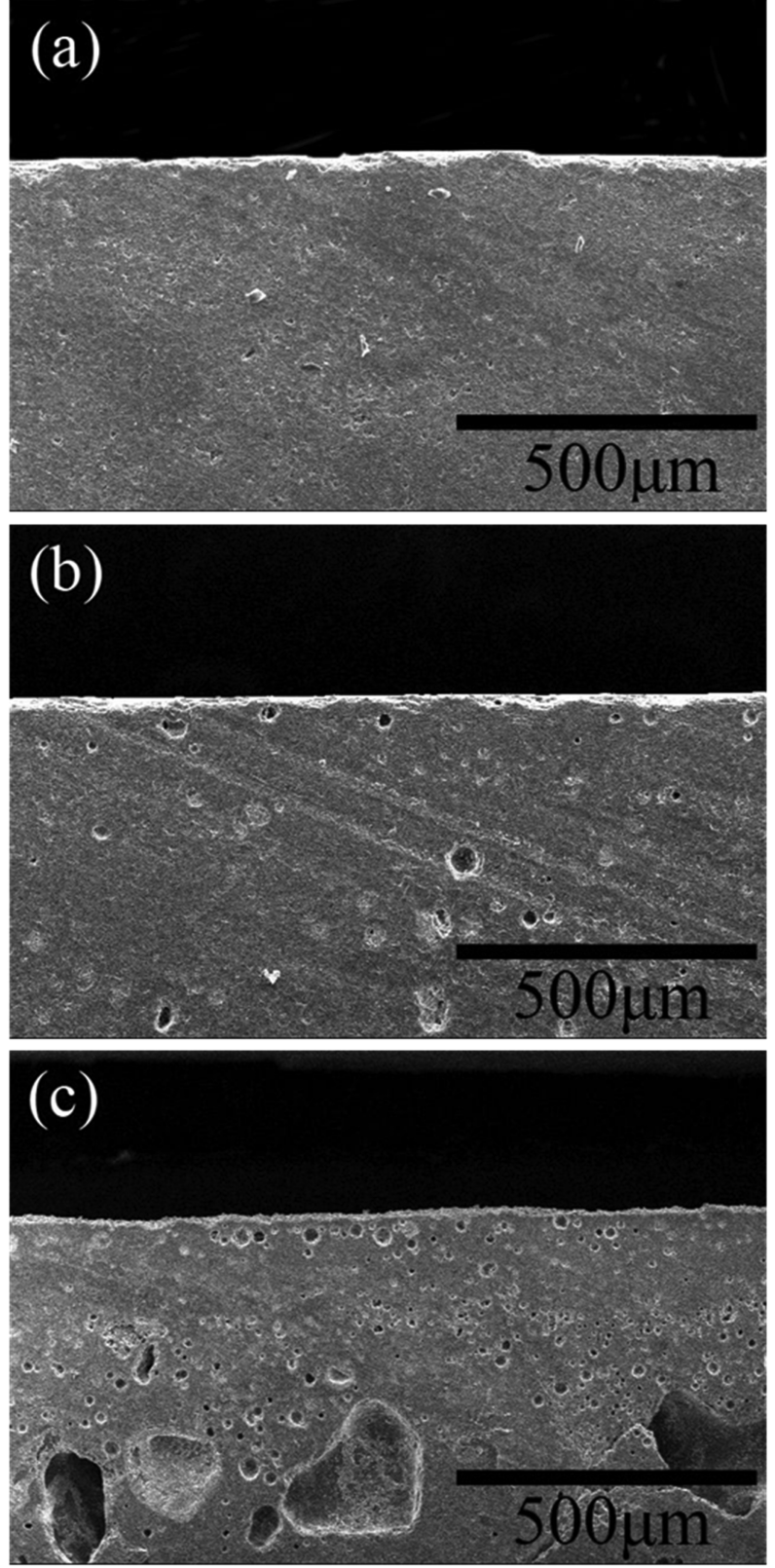

Fig. 5. SEM microstructures (low magnification) of samples heattreated at $1250^{\circ} \mathrm{C}$, infiltrated with (a) $0 \mathrm{wt} \%$ (b) $9 \mathrm{wt} \%$, and (c) $16 \mathrm{wt} \%$ lithium solution.

혹은 리튬화합물의 상대적인 양에 의하여 $\mathrm{Li}_{2} \mathrm{O}$ 와 $\mathrm{SiO}_{2}$ 와 의 반응 및 재결정화에 영향을 주어, 시편의 표면상태가 유리상 혹은 결정상으로 존재하는 것으로 추측된다.

Fig. 7은 리튬용액을 침투하고 $1250^{\circ} \mathrm{C}$ 에서 열처리하여 치밀화시킨 시편의 열팽창 변화를 상온에서 $1000^{\circ} \mathrm{C}$ 까지 나타내었다. $1 \mathrm{wt} \%$ 리튬용액으로 제조된 시편의 열팽창 계수는 약 $6.0 \times 10^{-6}{ }^{\circ} \mathrm{C}$ 를 보였으며, $9 \mathrm{wt} \%$ 리튬용액으로 제조된 시편은 약 $1.0 \times 10^{-6} /{ }^{\circ} \mathrm{C}$ 를 보이며, 0 에 가까운 열 팽창계수를 나타내었다. $16 \mathrm{wt} \%$ 리튬용액으로 제조된 시 

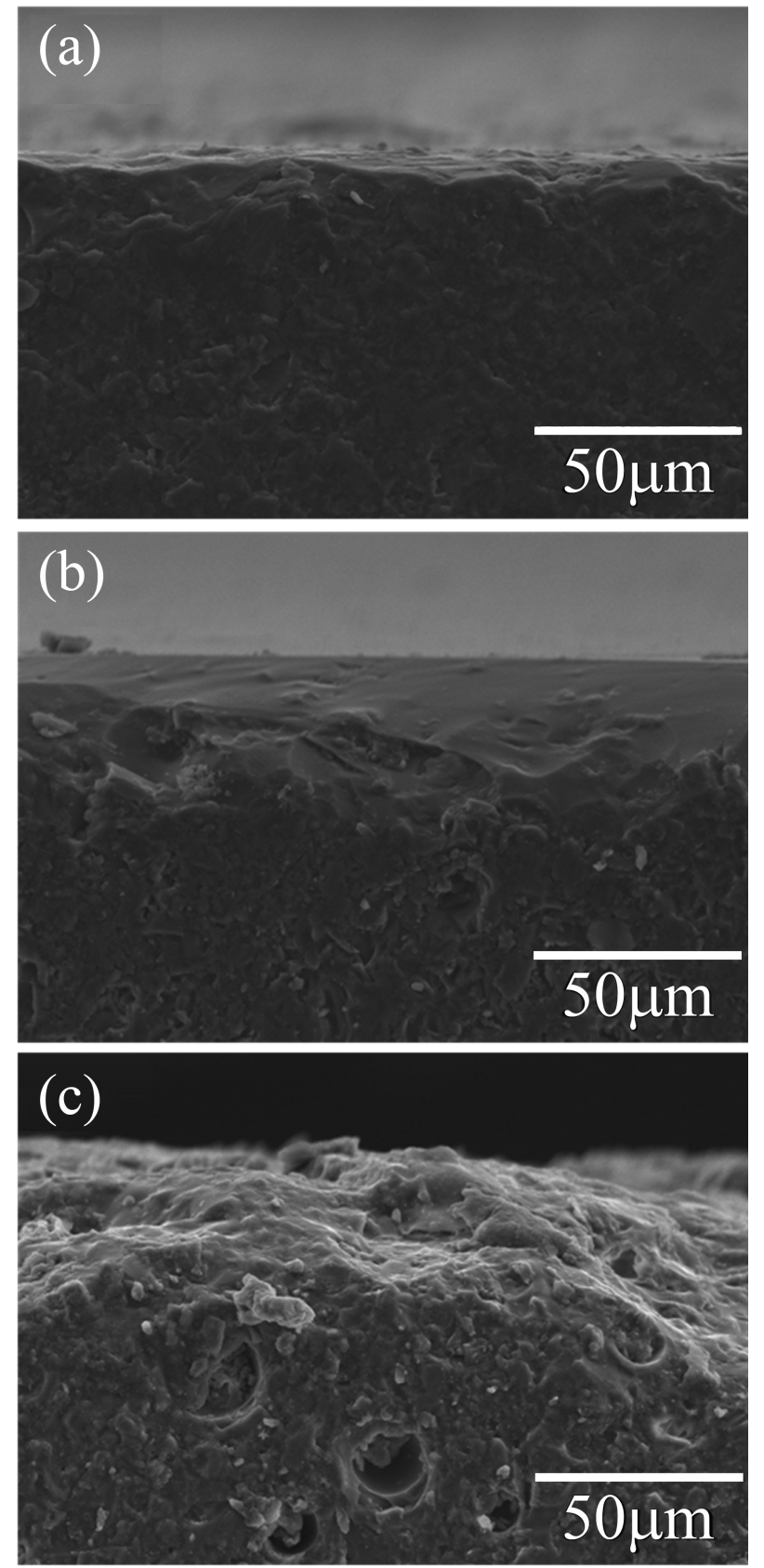

Fig. 6. SEM microstructures (high magnification) of samples heat-treated at $1250^{\circ} \mathrm{C}$, infiltrated with (a) $0 \mathrm{wt} \%$, (b) $9 \mathrm{wt} \%$, and (c) $16 \mathrm{wt} \%$ lithium solution.

편은 $9 \mathrm{wt} \%$ 리튬용액으로 제조된 시편과 유사한 열팽창 거동을 나타내었으며, Fig. 7에는 그 결과를 생략하였다.

\section{4. 결 론}

생활자기용 소지에 리튬용액을 침투시켜 내열충격성이 우수하고 치밀한 미세구조를 갖는 내열자기 제조가 가능 하였다. $9 \mathrm{wt} \%$ 의 수산화리튬이 용해된 수용액을 침투시

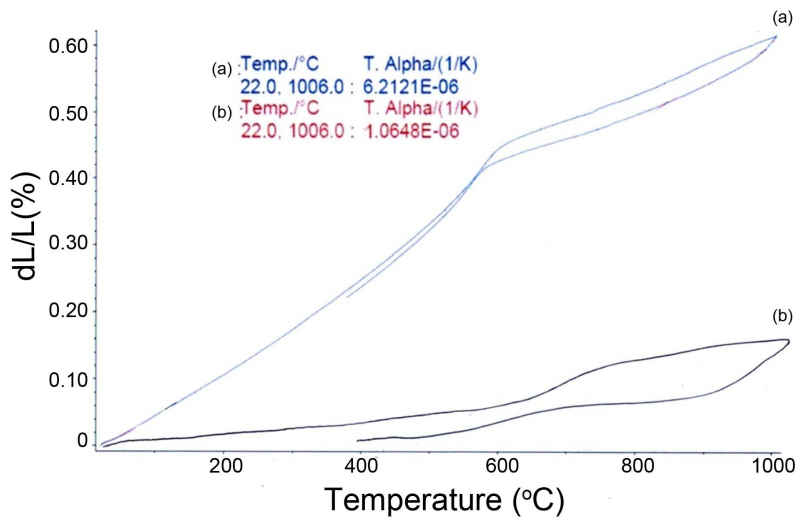

Fig. 7. Thermal expansion behavior of samples heat-treated at $1250^{\circ} \mathrm{C}$, infiltrated with (a) $1 \mathrm{wt} \%$ and (b) $9 \mathrm{wt} \%$ lithium solution.

킨 소지의 경우, $1250^{\circ} \mathrm{C}$ 열처리에 의하여 $1.0 \times 10^{-6}{ }^{\circ} \mathrm{C}$ 의 낮은 열팽창계수를 보이며 $\beta$-spodumene이 주 결정상인 치 밀한 소결체가 얻어졌다. 색상도 일반 생활자기에 근접한 백색도를 나타내었다. 리튬의 농도 차이에 따라 최종 시 편의 물성은 상이한 결과를 나타내었으며, 과량의 리틈 첨가 시에는 시편 표면과 내부의 리틈농도 차이에 따른 상이한 결정상과 리틈 용액 화합물의 용출에 따른 거대 기공의 발생으로 열충격 테스트 시 파괴가 발생하였다. 일반 생활자기 소지에 적당량의 리틈용액을 침투시키고 열처리하여 치밀화가 동반된 내열자기를 성공적으로 제 조할 수 있었으며, 이러한 연구결과의 응용은 향후 고기 능 내열세라믹 제품제조에 활용이 가능할 것으로 기대된다.

\section{REFERENCES}

1. L. M. Sheppard, "Ceramics for Controlling Diesel Emissions," Am. Ceram. Soc. Bull., 72 28-33 (1993).

2. B. Karmakar, P. Kundu, S. Jana, and R. N. Dwivedi, "Crystallization Kinetics and Mechanism of Low-Expansion Lithium Aluminosilicate Glass-Ceramics by Diatometry," J. Am. Ceram. Soc., 85 2572-74 (2002).

3. F. C. Serbena, V. Oliveira, O. Peitl, H. Pinto, R. Muccillo, and E. D. Zanotto, "Internal Residual Stresses in Sintered and Commercial Low Expansion $\mathrm{Li}_{2} \mathrm{O}-\mathrm{Al}_{2} \mathrm{O}_{3}-\mathrm{SiO}_{2}$ GlassCeramics," J. Am. Ceram. Soc., 94 [1] 206-14 (2011).

4. M. H. Lin and M. C. Wang, "Crystallization Behavior of $\beta$ Spodumene in the Calcinations of $\mathrm{Li}_{2} \mathrm{O}-\mathrm{Al}_{2} \mathrm{O}_{3}-\mathrm{SiO}_{2}-\mathrm{ZrO}_{2}$ Gels," J. Mater. Sci., 30 2716-21 (1995).

5. S. Knickerbocker, M. R. Tuzzolo, and S. Lawhorne, "Sinterable $\beta$-Spodumene Glasses-Ceramics," J. Am. Ceram. Soc., 72 1873-79 (1989).

6. E. J. Smoke, "Ceramics Compositions Having Negative Linear Thermal Expansion," J. Am. Ceram. Soc., 34 87-90 (1951).

7. C. E. Brackbill, H. A. Mckinstry, and F. A. Hummel, "Thermal Expansion of Some Glasses in the System $\mathrm{Li}_{2} \mathrm{O}-\mathrm{Al}_{2} \mathrm{O}_{3}$ - 
$\mathrm{SiO}_{2}$," J. Am. Ceram. Soc., 34 107-79 (1951).

8. M. J. Buerger, "Stuffed Derivatives of Silica Structures," Am. Mineral., 39 600-14 (1989).

9. H. C. Lee, "Synthesis of Low Thermal Expansion Ceramics Prepared from Pyrophyllite(in Korean)," pp. 1-63, M. S. Thesis, Mokpo Natl. Univ., Muan, 2011.

10. J. K. Kim, S. Y. Yang, and C. J. Jung, "Fabrication of Low TEC Machinable Ceramics Using Domestic Pyrophyllite(in Korean)," J. Kor. Ceram. Soc., 28 [9] 730-39 (1991).

11. H. S. Park, K. S. Cho, and C. S. Mun, "The Study on Fabrication of LAS System Ceramics for Thermal Shock Resistance from Silicate Minerals (III) Sintering Characteristics of Eucryptite and Spodumene(in Korean)," J. Kor. Ceram. Soc., 32 [2] 171-82 (1995).

12. R. Satyabrata and G. M. Muchow "High-Quartz, Solid Solution Phases from Thermally Crystallized Glasses of Compositions $\left(\mathrm{Li}_{2} \mathrm{O}, \mathrm{MgO}\right) \cdot \mathrm{Al}_{2} \mathrm{O}_{3} \cdot \mathrm{nSiO}_{2}$," J. Am. Ceram. Soc., 51 678-82 (1968).

13. L. Xia, G. Wen, L. Song, and X. Wang, "Sol-Gel Synthesis and Crystallization Behavior of $\beta$-Spodumene," J. Sol-Gel Sci. Technol., 52 134-39 (2009).

14. M. K. Naskar and M. Chatterjee, "A Novel Process for the Synthesis of Lithium Aluminum Silicate Powders from Rice Husk Ash and Other Water-Based Precursor Materials," Mater. Lett., 59 998-1003 (2005).

15. S. Mandal, S. Chakrabarti, and S. Ghatak, "Preparation and Characterization of a Powder Precursor, Consisting of
Oxides of Li-Al-Si in the Form of Hydroxyhydrogel for Synthesis of $\beta$-Spodumene Ceramics," Ceram. Int., $30357-$ 67 (2004).

16. W. Ostertag, G. R. Fischer, and J. P. Williams, "Thermal Expansion of Synthetic $\beta$-Spodumene and $\alpha$-SpodumeneSilica Solid Solution," J. Am. Ceram. Soc., 51 651-54 (1968).

17. H. T. Kim and E. S. Lee, "Preparation of the LAS Ceramics for Heat Resistance Using Metal Alkoxide (I)(in Korean)," J. Kor. Ceram, Soc., 30 [12] 987-92 (1993).

18. D. U. Tulyaganov, S. Agathopoulos, H. R. Fernandes, and J. M. F. Ferreira, "Synthesis of Lithium Aluminosilicate Glass and Glass-Ceramics from Spodumene Material," Ceram. Int., 30 1023-30 (2004).

19. S. Wu, Y. Liu, L. He, and F. Wang, "Preparation of $\beta$-Spodumene Based Glass Ceramic Powders by Polyacrylamide Gel Process," Mater. Lett., 58 2772-75 (2004).

20. K. O. Kim, "High-Intensity Heat Resistance Porcelain(in Korean)," Kor. Pat. 100924213 (2009).

21. D. L. Beaycganomp and M. Khajehpour, "The Effect of Lithium Ions on the Hydrophobic Effect : Does Lithium Affect Hydrophobicity Differently than Other Ions?," Biophys. Chem., 163-164 35-43 (2012).

22. G. I. Szasz, K. Heinzinger, and G. Palinkas, "The Structure of the Hydration Shell of the Lithium Ion," Chem. Phys. Lett., 78 194-96 (1981). 